\title{
Influence of split nitrogen application on yield and yield components of various maize varieties
}

\author{
Muhammad Mehran Anjum*, Muhammad Shafi, Haseeb Ahmad, \\ Nawab Ali, Muhammad Owais Iqbal, Saif Ullah, Shafiullah, \\ Muhammad Faheem Jan and Waqas Liaqat \\ Department of Agronomy, The University of Agriculture Peshawar,KPK-Pakistan \\ *Corresponding author's email: mehrananjum@aup.edu.pk \\ Citation
}

Muhammad Mehran Anjum, Muhammad Shafi, Haseeb Ahmad, Nawab Ali, Muhammad Owais Iqbal, Saif Ullah, Shafiullah, Muhammad Faheem Jan and Waqas Liaqat. Influence of split nitrogen application on yield and yield components of various maize varieties. Pure and Applied Biology. Vol. 7, Issue 2, pp721-726. http://dx.doi.org/10.19045/bspab.2018.70090

\begin{tabular}{|c|c|c|c|}
\hline Received: 04/03/2018 & Revised: 04/06/2018 & Accepted: 19/06/2018 & Online First: 25/06/2018 \\
\hline
\end{tabular}

\section{Abstract}

Maximum soils of the Pakistan are $\mathrm{N}$ deficient. The Nitrogen applied to the soil can be leached down in soil below the root zone of the crop while some of the Nitrogen gets volatized in the atmosphere which can adversely affect the crop growth and development of corn plants so application timing of nitrogen in maize has a great importance and considered the best and appropriate for production of maize. Nitrogen application is required by the maize plants when needed and is taken at higher rates could improve nitrogen use effectiveness by diminishing the denitrification and immobilization. The study entitled "Influence of split nitrogen application on yield and yield components of maize" was carried out during 2016 at the Research Farms of Agronomy, The University of Agriculture Peshawar. Four split nitrogen applications were assigned to main plots while the varieties were assigned to sub plots. Experimental results exhibited that application of nitrogen in three split, $60 \mathrm{~kg} \mathrm{ha}^{-1}$ before sowing $+60 \mathrm{~kg} \mathrm{ha}^{-1}$ at knee height stage $+60 \mathrm{~kg} \mathrm{ha}^{-1}$ before tasseling stage has produced taller plants, maximum ear length, thousand grains weight, biological yield, grain yield, shelling percentage and harvest index. Among various varieties, Azam has produced maximum thousand grains weight, biological yield and grain yield. It is concluded that nitrogen applied in three splits $\left(60 \mathrm{~kg} \mathrm{ha}^{-1}\right.$ before sowing $+60 \mathrm{~kg} \mathrm{ha}^{-1}$ at knee height stage $+60 \mathrm{~kg} \mathrm{ha}^{-1}$ before tasseling stage) and Azam variety of maize crop has produced maximum grain yield.

Keywords: Azam; Biological yield; Grain yield; Nitrogen; Split; Varieties

\section{Introduction}

Maize (Zea mays L.) is an important grain crop in the world. Maize ranked $3^{\text {rd }}$ in term of area and production. Maize is an essential food crop with high nutrition value. Maize is also used as feed for livestock and it contains $4.8 \%$ oil, $8.5 \%$ fiber, $72 \%$ starch, $10 \%$ protein, $3 \%$ sugar and $1.7 \%$ ash [1]. In Pakistan maize was cultivated on an area 1.114 and 0.447 million hectares with an average yield of 4301 and $1985 \mathrm{~kg} \mathrm{ha}^{-1}$ and in Khyber Pakhtunkhwa respectively with production was 4.920 and 0.887 million tons $\mathrm{ha}^{-1}[2]$. Nitrogen deficiency is the yield restricting factor which reduces grain yield $[3,4]$ reported that application of nitrogen with greater amount increases total production 
cost and it increases leaching, volatilization and immobilization. However, split application of $\mathrm{N}$ can nourish the crop better through optimum $\mathrm{N}$ uptake and thus protects the environment from the adverse effect of these chemical inputs. Likewise when deficiency of $\mathrm{N}$ occur in the crop plant so the leaf area of the plant get decreases and thus the interception of light is adversely affected due to vegetative growth [5]. Application timing of nitrogen in maize has a great importance and considered the best and appropriate for production of maize. Nitrogen application is required by the maize plants when needed and is taken at higher rates could improve nitrogen use effectiveness by diminishing the denitrification and immobilization $[6,7]$. Maximum soils of the Pakistan are $\mathrm{N}$ deficient [8]. In order to get maximum and appropriate yield, increasing the nitrogen use efficiency by crop could be achieved through best management practices of nitrogen [9].

Keeping in view the importance of nitrogen application in splits doses on yield performance of maize, the present research studied was planned to study the effects of split $\mathrm{N}$ application on yield and yield components of maize.

\section{Materials and methods}

The experiment was conducted at Research Farm of Agronomy, the University of Agriculture Peshawar during kharif season 2016. The research comprised main plot factor (Split Nitrogen Application) i.e. Control, $180 \mathrm{~kg} \mathrm{ha}{ }^{-1}$ before sowing, $90 \mathrm{~kg} \mathrm{ha}^{-1}$ before sowing, + $90 \mathrm{~kg} \mathrm{ha}^{-1}$ at knee height stage, $60 \mathrm{~kg} \mathrm{ha}^{-1}$ before sowing $+60 \mathrm{~kg} \mathrm{ha}^{-1}$ at knee height stage $+60 \mathrm{~kg} \mathrm{ha}^{-1}$ before tasseling stage, $45 \mathrm{~kg} \mathrm{ha}^{-1}$ before sowing $+45 \mathrm{~kg} \mathrm{ha}^{-1}$ at knee height stage $+45 \mathrm{~kg} \mathrm{ha}^{-1}$ before tasseling stage $+45 \mathrm{~kg} \mathrm{ha}^{-1}$ before silking stage and sub plot factor (varieties) i.e. (Pahari, Azam, Jalal and Iqbal). The trail was carried out in Randomized Complete Block Design (RCB) with Split Plot arrangement comprised of four replications.
The sub plot was $12 \mathrm{~m}^{2}(3 \mathrm{~m} \times 4 \mathrm{~m})$ in size having five rows. Nitrogen was applied from the source of Urea. Phosphorous was applied from the source of DAP. Crop was cultivated on proper moisture condition. During the crop growth \& developmental stages weeds were controlled manually as well as chemically. Haywer, herbicide was sprayed at 4-5 leaf stage for weeds (25 days after sowing) of maize crop to control both broad leaf and grassy weeds. For all treatments, agronomic practices were kept uniform. At the physiologically maturity stage, height of the five representative plants from the soil surface till the tip of tassel in each sub unit were measured by using meter rod and then averaged. Ear length was measured by the help of meter rod by the selection of 10 representative samples in each subplot and averaged. Thousand grains weight was recorded through the random selection of sample from the grains of each unit, weighed through sensitive electronic balance. Biomass yield for all experimental unit was measured through the harvesting of four central rows in each experimental unit, placed on floor for sun drying, weighed through balance and converted to $\mathrm{kg} \mathrm{ha}^{-1}$. Plants, which were harvested for biomass yield, were dehusked, dried, threshed then weighed through electronic balance for grain yield and converted to grain yield per $\mathrm{kg} \mathrm{ha}^{-1}$. Data on shelling percentage was calculated for each experimental unit by the following formula:

Shelling $(\%)=$ Grain wt. of ten ears/ total wt. of 10 ears x 100

Harvest index (\%) for each experimental unit was calculated through their respective grain yield and biomass yield by formula given below.

$$
\begin{aligned}
& \mathrm{HI} \%=\frac{\text { Grain Yield }(\mathrm{Kg} / \mathrm{ha})}{\text { Biological Yield (Kg/ha) }} \times 100 \\
& \text { Statistical analysis }
\end{aligned}
$$

\section{Statistical analysis}

The recorded data was statistically analyzed by the technique of ANOVA (analysis of variance) using Statistix 8.1 package for RCBD (randomized complete 
block design) with split plot arrangement by using least significant difference (LSD) $5 \%$ significance level $(\mathrm{P} \leq 0.05)$ upon significant F-test by the procedure of [10].

\section{Results and discussion Plant height (cm)}

Different varieties of maize and split nitrogen application had significantly $(\mathrm{P} \leq 0.05)$ affected plant height of maize crop (Table 1). Interaction of varieties and split nitrogen application had nonsignificantly affected the plant height of maize. Maximum plant height was recorded from treatment of nitrogen application in three split $60 \mathrm{~kg} \mathrm{ha}^{-1}$ before sowing $+60 \mathrm{~kg} \mathrm{ha}^{-1}$ at knee height stage + $60 \mathrm{~kg} \mathrm{ha}^{-1}$ before tasseling stage. Application of nitrogen in two split, $90 \mathrm{~kg}$ $\mathrm{ha}^{-1}$ at sowing $+90 \mathrm{~kg} \mathrm{ha}^{-1}$ at knee height stage and single application of nitrogen 180 $\mathrm{kg} \mathrm{ha} \mathrm{h}^{-1}$ before sowing ranked $2^{\text {nd }}$ and $3^{\text {rd }}$ in term of plant height. Lowest value for plant height was recorded from the treatment of control (No nitrogen was applied). The plant height increased with more nitrogen splits application i.e. 3 splits. It may be due to supply of proper amount of $\mathrm{N}$ at different growth stages of maize. The $\mathrm{N}$ promotes plant growth, increase the number and length of internodes which resulted in taller plants of maize crop [11]. Highest plant height was recorded from maize variety Azam followed by Iqbal. Lowest plant height was recorded from Pahari variety. The difference in plant height of different maize varieties may be due to diverse genetic background of the varieties which resulted in varying plant height. Our results are in line with [12] who reported that different varieties have different plant height.

\section{Ear length $(\mathbf{c m})$}

Nitrogen application in split and different varieties of maize have significant $(\mathrm{P} \leq 0.05)$ effect on ear length. The combined effects of split nitrogen application and varieties have nonsignificantly effect. Maximum ear length was observed from treatment of nitrogen in three split application $\left(60 \mathrm{~kg} \mathrm{ha}^{-1}\right.$ before sowing $+60 \mathrm{~kg} \mathrm{ha}^{-1}$ at knee height stage + $60 \mathrm{~kg} \mathrm{ha}^{-1}$ before tasseling stage) followed by two splits. Lowest ear length was recorded from control plots. Maximum ear length at 3 split application of nitrogen has decreased nitrogen loses and provided an adequate amount of nitrogen to the plant which showed more increase in vegetative growth and hence increased length of ear. Similar results were reported by [13] who reported that highest cob length in nitrogen fertilized plots and smallest cob length in the plots where nitrogen was not applied. Highest value for ear length was recorded from Azam variety followed by Iqbal and Jalal variety. Pahari variety showed lowest ear length. The variation in ear lengths of maize varieties might be due to the genetic potential of these varieties.

\section{Thousand grains weight $(\mathrm{g})$}

Data concerning thousand grains weight of maize was significantly affected by split nitrogen application as well as varieties, is shown in (Table 1). Interaction of split nitrogen application and varieties had nonsignificant impact. Maximum thousand grains weight was recorded from treatment of nitrogen in three equal splits i.e. $60 \mathrm{~kg}$ $\mathrm{ha}^{-1}$ before sowing $+60 \mathrm{~kg} \mathrm{ha}^{-1}$ at knee height stage $+60 \mathrm{~kg} \mathrm{ha}^{-1}$ before tasseling stage followed by nitrogen application in four splits i.e. $45 \mathrm{~kg} \mathrm{ha}^{-1}$ before sowing +45 $\mathrm{kg} \mathrm{ha}^{-1}$ at knee height stage $+45 \mathrm{~kg} \mathrm{ha}^{-1}$ before tasseling stage $+45 \mathrm{~kg} \mathrm{ha}^{-1}$ at silking stage. Minimum thousand grains weight was recorded from control. It may possibly be due to the availability of optimum nitrogen in three equal splits throughout the growing season. Similar results were declared by $[14,15]$ who reported that application of nitrogen at critical growth stages significantly affected thousand grains weight in maize. Highest thousand grains weight was recorded from Azam variety followed by Iqbal. Minimum thousand grains weight was documented for Pahari variety of maize. The possible reason for difference among varieties for grains weight might be the genotypic characteristic of the varieties [16]. 


\section{Biological yield (kg ha-1)}

Biological yield of maize varieties as affected by split nitrogen application is presented in (Table 1). The interaction between split nitrogen application and varieties had non-significant effect. Maximum biological yield was recorded from nitrogen applied in three splits i.e. 60 $\mathrm{kg} \mathrm{ha}^{-1}$ before sowing $+60 \mathrm{~kg} \mathrm{ha}^{-1}$ at knee height stage $+60 \mathrm{~kg} \mathrm{ha}^{-1}$ before tasseling stage followed by application of nitrogen in two splits. Lowest value for biological yield was observed from control plots. The highest biological yield may be due to application of nitrogen in splits doses and hence nitrogen was efficiently utilized by crop according to its requirements. [17, 18] reported that nitrogen application at vegetative stage of maize prolonged growth phases and produced more assimilates that resulted in higher biological yield of maize crop. Highest biological yield was recorded from Azam variety as compared to other tested maize varieties while lowest biological yield was harvested from Pahari variety.

\section{Grain yield ( $\left.\mathrm{kg} \mathrm{ha}^{-1}\right)$}

Grain yield of maize was significantly influenced by split nitrogen application as well as varieties are presented in (Table 1). Interaction of split nitrogen application and varieties had non-significant effect. Maximum grain yield was recorded from nitrogen in three split application i.e. $60 \mathrm{~kg}$ $\mathrm{ha}^{-1}$ before sowing $+60 \mathrm{~kg} \mathrm{ha}^{-1}$ at knee height stage $+60 \mathrm{~kg} \mathrm{ha}^{-1}$ before tasseling stage followed by application of nitrogen in four splits i.e. $45 \mathrm{~kg} \mathrm{ha}^{-1}$ before sowing +45 $\mathrm{kg} \mathrm{ha}^{-1}$ knee height stage $+45 \mathrm{~kg} \mathrm{ha}^{-1}$ before tasseling stage $+45 \mathrm{~kg} \mathrm{ha}^{-1}$ at silking stage. Lowest grain yield was observed from control. The application of nitrogen in three equal splits has ensured the availability of nitrogen at all the essential growth stages of the maize crop. The losses of nitrogen were reduced due to split application which facilitated efficient uptake of nitrogen during growing season of maize crop. [19, 20] reported that split nitrogen application has ensured high yield performance in maize crop. Maximum grain yield was harvested from Azam variety of maize followed by Jalal and Iqbal. Lowest grain yield $\mathrm{kg} \mathrm{ha}^{-1}$ was recorded from Pahari variety. The higher grain yield recorded for Azam variety could be due to maximum ear length and thousand grains weight that ultimately increased grain yield.

\section{Shelling percentage $(\%)$}

Data on shelling percentage of maize was significantly affected by split nitrogen application is given in (Table 1). Varieties and interaction between nitrogen split application and varieties was found not significant. Highest value for shelling percentage was recorded from treatment of nitrogen in three split application followed by two splits. Lowest value for shelling percentage was recorded for control. Our results were strongly in agreement with [21] reported that highest shelling percentage can be obtained by the application of nitrogen in thrice splits.

\section{Harvest index (\%)}

Harvest index of maize was significantly influenced by split nitrogen application (Table 1). Maize varieties and its interaction with split nitrogen application were non-significant. Maximum harvest index was recorded from treatment of nitrogen applied in three splits $\left(60 \mathrm{~kg} \mathrm{ha}^{-1}\right.$ before sowing $+60 \mathrm{~kg} \mathrm{ha}^{-1}$ at knee height stage $+60 \mathrm{~kg} \mathrm{ha}^{-1}$ before tasseling stage followed by two splits. Minimum harvest index was recorded from control. [22, 23] reported that harvest index increased when application of nitrogen in split is increased. 
Table 1. Plant height $(\mathrm{cm})$, ear length $(\mathrm{cm})$, thousand grains weight $(\mathrm{g})$, biological yield $\left(\mathrm{kg} \mathrm{ha}^{-1}\right)$, grain yield $\left(\mathrm{kg} \mathrm{ha}^{-1}\right)$, shelling percentage and harvest index of maize varieties as influenced by split nitrogen application

\begin{tabular}{|c|c|c|c|c|c|c|c|}
\hline $\begin{array}{l}\text { Nitrogen } \\
\left(\mathrm{Kg} \mathrm{ha}^{-1}\right)\end{array}$ & $\begin{array}{c}\text { Plant } \\
\text { height } \\
(\mathbf{c m})\end{array}$ & $\begin{array}{c}\text { Ear } \\
\text { length } \\
(\mathrm{cm}) \\
\end{array}$ & $\begin{array}{c}\text { Thousand } \\
\text { grains } \\
\text { weight (g) }\end{array}$ & $\begin{array}{c}\text { Biological } \\
\text { yield }\left(\mathrm{kg} \mathrm{ha}^{-1}\right)\end{array}$ & $\begin{array}{l}\text { Grain yield } \\
\quad\left(\mathrm{kg} \mathrm{ha}^{-1}\right)\end{array}$ & $\begin{array}{c}\text { Shelling } \\
\text { \%age }\end{array}$ & $\begin{array}{c}\text { Harvest } \\
\text { index }(\%)\end{array}$ \\
\hline $\mathrm{N}_{0}$ & $179.7 b$ & $12.2 \mathrm{c}$ & $224.9 \mathrm{c}$ & $10239 \mathrm{c}$ & $2563 c$ & $55 \mathrm{c}$ & $25 \mathrm{c}$ \\
\hline $\mathrm{N}_{1}$ & $183.3 \mathrm{ab}$ & $13.2 b$ & $232.4 b c$ & $10552 \mathrm{bc}$ & $2687 \mathrm{c}$ & $55 c$ & $26 c$ \\
\hline $\mathrm{N}_{2}$ & $185.2 \mathrm{ab}$ & $13.8 \mathrm{ab}$ & $236.6 b$ & $11227 \mathrm{a}$ & $3490 b$ & $70 \mathrm{ab}$ & $31 b$ \\
\hline $\mathrm{N}_{3}$ & $189.2 \mathrm{a}$ & $14.6 \mathrm{a}$ & $246.1 \mathrm{a}$ & $11247 \mathrm{a}$ & $4197 \mathrm{a}$ & $76 a$ & $37 \mathrm{a}$ \\
\hline $\mathrm{N}_{4}$ & $180.9 b$ & $12.9 \mathrm{bc}$ & $240.1 \mathrm{ab}$ & $10914 \mathrm{ab}$ & $3473 b$ & $66 b$ & $32 b$ \\
\hline \multicolumn{8}{|l|}{ Varieties } \\
\hline Pahari & $180.1 b$ & $12.4 \mathrm{~b}$ & $230.1 \mathrm{c}$ & $10580 \mathrm{~b}$ & $3152 b$ & 68 & 30 \\
\hline Azam & $188.2 \mathrm{a}$ & $14.0 \mathrm{a}$ & $241.7 \mathrm{a}$ & $11223 \mathrm{a}$ & $3393 a$ & 61 & 30 \\
\hline Jalal & $182.6 \mathrm{ab}$ & 13.0ab & $234.3 b c$ & $10784 b$ & $3294 \mathrm{ab}$ & 65 & 31 \\
\hline Iqbal & $183.9 \mathrm{ab}$ & $13.9 \mathrm{a}$ & $238.0 \mathrm{ab}$ & $10757 b$ & $3287 \mathrm{ab}$ & 64 & 31 \\
\hline $\begin{array}{l}\text { LSD for } \\
\text { Nitrogen }\end{array}$ & 6.99 & 0.95 & 7.82 & 459.6 & 164.7 & 7.67 & 2.19 \\
\hline $\begin{array}{l}\text { LSD for } \\
\text { Varieties }\end{array}$ & 5.7 & 1.02 & 7.3 & 361.1 & 158.1 & ns & ns \\
\hline Interaction & $\mathrm{ns}$ & Ns & ns & ns & ns & ns & ns \\
\hline
\end{tabular}

$\mathrm{N}_{0}=$ control (Zero nitrogen)

$\mathrm{N}_{1}=180 \mathrm{~kg} \mathrm{ha}^{-1}$ before sowing

$\mathrm{N}_{2}=90 \mathrm{~kg} \mathrm{ha}^{-1}$ before sowing $+90 \mathrm{~kg} \mathrm{ha}^{-1}$ at knee height stage

$\mathrm{N}_{3}=60 \mathrm{~kg} \mathrm{ha}^{-1}$ before sowing $+60 \mathrm{~kg} \mathrm{ha}^{-1}$ at knee height stage $+60 \mathrm{~kg} \mathrm{ha}^{-1}$ before tasseling stage

$\mathrm{N}_{4}=45 \mathrm{~kg} \mathrm{ha}^{-1}$ before sowing $+45 \mathrm{~kg} \mathrm{ha}^{-1}$ at knee height stage $+45 \mathrm{~kg} \mathrm{ha}^{-1}$ before tasseling stage $+45 \mathrm{~kg} \mathrm{ha}^{-1}$ before silking stage

ns $=$ non-significant

\section{Conclusion}

It can be concluded from the study that nitrogen application in three splits i.e. 60 $\mathrm{kg} \mathrm{ha}^{-1}$ before sowing $+60 \mathrm{~kg} \mathrm{ha}^{-1}$ at knee height stage $+60 \mathrm{~kg} \mathrm{ha}^{-1}$ before tasseling stage has produced maximum grain yield. Among varieties, Azam performed better in terms of grain yield. Thus, application of nitrogen in three splits to maize variety, Azam is recommended for higher grain yield under the agro-climatic conditions of Peshawar region.

\section{Authors' contributions}

Conceived and designed the experiments: MM Anjum \& M Shafi, Performed the experiments: N Ali \& H Ahmad, Analyzed the data: W Liaqat \& MF Jan, Contributed materials/ analysis/ tools: MO Iqbal, Shafiullah \& S Ullah, Wrote the paper: MM Anjum.

\section{References}

1. Chaudhry AR (1983). Effect of $\mathrm{N}$ application and $\mathrm{N}$ spliting strategy on maize $\mathrm{N}$ uptake biomass production and physio-agronomic characteristics. Sarhad J Agric 26(4): 551-558.

2. MNFSR (2015). Agriculture Statistics of Pakistan. Ministry of National Food Security and Research, Islamabad, Pakistan.

3. Moser SB, Feil B, Jampatong S \& Stamp P (2006). Effects of preanthesis drought, nitrogen fertilizer rate, and variety on grain yield, yield components, and harvest index of tropical maize. Agric Water Manage 81: 41-58.

4. Grant CA, Peterson GA \& Campbell CA (2002). Nutrient considerations for diversified cropping systems in the northern great plains. Agron $J$ 94: 186-198.

5. Uhart SA \& Andrade FH (1995). Nitrogen deficiency in maize: II. Carbon-nitrogen interaction effects on 
kernel number and grain yield. Crop Sci 35: 1384-1389.

6. Walsh OS (2006). Effect of Delayed Nitrogen Fertilization on Corn Grain Yields. M. Sc. Thesis. Graduate College. Oklahoma State Uni Oklahoma.

7. Rizwan M, Maqsood M, Rafiq M, Saeed M \& Ali Z (2003). Maize (Zea mays) Response to split application of nitrogen. Int J Agric Bio 1560-8530.

8. Rashid A, Ahmad N, Ahmad S \& Ahmad T (1993). Source sink relationship in maize under varying nitrogen regimes. Pak Agric Res 14(2): 173-176.

9. Rehmati H (2009). Effect of plant density and nitrogen rates on yield and nitrogen use efficiency of grain corn. Applied Sci J 7(8): 958-961.

10. Jan MT, Shah P, Hollington PA, Khan MJ \& Sohail Q (2009). Agriculture research: design and analysis, a monograph. Agric Univ Pesh Pak.

11. Adhikari P, Baral BR \& Shrestha J (2016). Maize response to time of nitrogen application and planting seasons. J Maize Res Develop 2(1): 83-93.

12. Thakur DR, Prakash O, Kharwara PC \& Bhalla SK (1997). Effect of nitrogen and plant spacing on yield, nitrogen uptake and economics in baby corn (Zea mays L.). Indian $J$ Agron 43(4): 668-671.

13. Sharifi SR \& Taghizadeh (2009). Response of maize (Zea mays L.) cultivars to different levels of nitrogen fertilizer. J Food Agric Environ 7(3): 518-521.

14. Sharma RN (1980). Effect of planting techniques and time and method of fertilizer application on Maize (Ganga - 3). Indian J Agron 25: 359 -555.

15. Miller HF, Kawanaugh J, \& Thomus GW (1975). Time of application and yield of corn in wet alluvial soils. Agron J 67: 401-4.

16. Shah STH, Zamir MSI, Waseem M, Ali A, Tahir M, \& Khalid WB (2009). Growth and yield response of maize (Zea mays L.) to organic and inorganic sources of nitrogen. Pak $J$ Life Soc Sci 7(2): 108-111.

17. Amanullah, Khattak AR, \& Khalil SK (2009). Plant density and nitrogen effects on maize phenology and grain yield. J Plant Nutri 32: 246-260.

18. Arif M, Amin I, Jan MT, Munir I, Nawab K, Khan NU \& Marwat KB (2010). Effect of plant population and nitrogen levels and methods of application on ear characters and yield of maize. Pak J Bot 42(3):1959-1967.

19. Debele T \& Bedadi B (2016). Effect of drain depth of vertisols, nitrogen source and time of application on yield and yield components of maize (Zea mays L.) In ambo, western ethiopia. Int J Res Studies Agric sci 2(6): 1-9.

20. Sarafraz R \& Marashi SK (2015). Effect of split application of nitrogen fertilizer on quantitative and qualitative characteristics of maize under water deficit condition. Indian $J$ Fund Appl Life Sci 5(1): 172-178.

21. Wasaya A, Tahir M, Tanveer A \& Yaseen M (2012). Response of maize to tillage and nitrogen management. $J$ Anim Plant Sci 22(2): 452-456.

22. Lawrence JR, Ketterings QM, Cherney JH (2008). Effect of nitrogen application on yield and quality of corn. Agron J 100(1): 73-9.

23. Zeidan MS, Amany A, \& El-Kramany MF (2006). Effect of N-fertilizer and plant density on yield and quality of maize in sandy soil. Res J Agric Biol Sci 2(4): 156-61. 